across Lake Constance. After two days in prison he at last obtained his permit of emigration, and on March 4, 1939, was received by friends in Switzerland. With Aristides, he felt it hardest that his fatherland had dishonoured itself by banning him.

The book was begun soon after he settled at "Eremit. agio" in Muralto-Locarno, finished in December 1940 and was intended to be further revised. Those who knew him will recognize by style and substance a life-like picture of the author and his ways. The record of many events in his life takes the form of anecdotes; they are not pointless reminiscences of an old man in his 'anecdotage', but are as incisive as his methods of research. While tempered by a genuine sense of humour, they mostly have a sting in their tail. Although fully aware that few of those mentioned would be pleased, he is scrupulously fair to all, not least to those who have done him wrong. $\mathrm{He}$ dedicated the book "to his devoted pupils", who owed more to him than he to them. He pays generous tribute to others, for example, to Sir Robert and Lady Robinson for continuing his own work on anthocyanins by their masterly investigations and syntheses of natural glucosides.

The author did not "wish to write a chemical book, nor to digress too far from the life of a chemist". His success in both directions is exemplified by his inability to dissociate even the most intimate domestic events from his work; thus, he fixes the birth of his daughter by his work on complex magnesium in chlorophyll, and the death of his wife by that on the colourless orthoquinone. This interweaving of life and science throughout the book makes it an unusually interesting document of the work and personality of one of the greatest figures of his generation in the world of chemistry.

The author's own story ends with his final departure from the country of his birth. It is taken up in an epilogue by the editor, Prof. Arthur Stoll, his favourite pupil and former assistant, who befriended him in his exile. Prof. Stoll, with a devotion for which all Willstätter's friends will be grateful, records letters and conversations during the last three years of his master's life, in which he discusses the progress of the autobiography, the publication of his last researches and new proposals for the technical preparation of certain drugs. In the quietude of his newly found Swiss home and garden, Willstätter shed all bitterness and regained his innate serenity of mind. He worked uninterruptedly until in December 1941 his weakened heart began to give him trouble. He died on August 3, 1942, ten days before his seventieth birthday.

Credit is due to the publishers for the excellent production of the book and the quality of the illustrations, some of which are of historical interest.

R. LESSING

\section{SOCIAL OR COMMUNITY MEDICINE}

Recent Advances in Social Medicine

By Prof. Alan Carruth Stevenson. Pp. viii +241. (London: J. and A. Churchill, Ltd., 1950) 18s, net.

CINCE social medicine has become a familiar $\checkmark$ expression in Great Britain, there has been a great deal of discussion about its meaning, and no general agreement has been reached. Prof. A. C.
Stevenson, in his book in the "Recent Advances" series, wisely refrains from flogging a dead horse by adding to the controversy. Whether social medicine is regarded as an academic discipline in its own right or as a particular way of viewing a wide range of medical problems, it is clear that the subject has a considerable statistical content, if only for the reason that, however regarded, social medicine interests itself mainly in health and disease in the mass. It is not surprising, therefore, that a good half of the 241 pages of this book is taken up mainly by medical and social statistics and relevant accounts of statistical methods. Chapter 13, written by Dr. E. A. Cheeseman, is particularly noteworthy in this respect. This chapter includes a simple and lucid account of the Registrar General's social classes and of the use of regression equations, which will be welcomed by many medical readers. Dr. Cheeseman's treatment of regression equations would probably be somewhat tedious for a mathematical reader, but to say this is to confirm that he has succeeded in describing methods unfamiliar to most medical men in a manner which makes them "intelligible to those not accustomed to think in mathematical terms".

Two chapters on infant mortality and allied subjects are also mainly statistical. The assembling and ordering of a wealth of data in these chapters is something few readers could conveniently do for themselves. Medical officers, pædiatricians and others will obtain from the fifty-odd pages a great deal of valuable information for a small expenditure of reading-time.

Anyone, however, who holds the mistaken belief that social medicine is a desiccated aggregate of figures, sums and numerical conclusions needs only to read the reasoned plea of Prof. Stevenson for a square deal for the 'girl in trouble'-a plea concluded by the observation that "the problem is one of Disabled Persons and of Rehabilitation rather than one of moral reform" ; or for that matter he needs only to turn to the examination of the social and economic disorders inimical to family life in relation to the provision of day nurseries for young children. In the middle chapters of the book both these subjects are dealt with, namely, "The Health of Children in Communal Day Nurseries", and "The Unmarried Mother and her Child" ; and there is also a chapter on "Problem Families". Though all these chapters are substantiated by numerical data, they convey to the reader the essential humanity of the social medical approach to some of the important problems of our day. A short note towards the end of the book on psychosomatic illness has not the clarity which marks other chapters-but, perhaps, this is scarcely surprising. The first chapter on the "Measurement and Growth in Children" makes somewhat heavy reading; it is, perhaps, one to be left for an hour of greater effort than the rest of a highly readable book requires.

Prof. Stevenson never shirks stating his views in firm terms, and this feature of the book is both refreshing and stimulating, whatever minor differ. ences of interpretation the reader may arrive at on the facts. References given chapter by chapter are a valuable feature for students or research workers; and, all told, the book should not only be on the library shelves of medical officers of health, pædiatricians, D.P.H. and D.C.H. students and social workers, but should also be read with pleasure by all of them before being placed there.

F. GRUNDY 